\title{
Analysis of Training Program in Front Office Department at Aryaduta Bali Hotel
}

\author{
Luh Putu Diah Ayu Savitri*1, I Gusti Agung Gede Witarsana², Desak Gede Chandra \\ Widayanthi'3 I Wayan Restu Darmawan ${ }^{4}$ \\ Politeknik Pariwisata Bali, Indonesia1,2,3,4 \\ Email: chandrawida@ppb.ac.id
}

\begin{abstract}
Training program evaluation is highly necessary and important to improve the business, particularly in the hospitality business. The aim of this research is to analyze the quality of training programs held for employees in the Front Office Department at Aryaduta Bali Hotel based on the Kirkpatrick Model and finding out a possible suggestion for improvement that could be done to enhance the quality of training programs. The data for this study was obtained by distributing an online questionnaire and conducting interviews. To validate the data, testing was done through data triangulation. As a result of this study, there are 2 criteria that show that the training program needs improvements more on how to satisfy the participants and how to more effectively evaluate the program. To improve these aspects, anonymous evaluation to gather detailed and objective input from the participant is suggested to be done.
\end{abstract}

Keywords: Training Evaluation, Kirkpatrick's Model, Training

\begin{abstract}
Abstrak
Training atau pelatihan adalah hal yang penting untuk dilakukan dalam meningkatkan bisnis, terlebih dalam bisnis hospitaliti. Tujuan dari penelitian ini adalah untuk menganalisis kualitas training yang dilaksanakan untuk karyawan di bagian Kantor Depan Hotel Aryaduta Bali berdasarkan Model Kirkpatrick dan merumuskan saran yang tepat untuk meningkatkan kualitas training. Data penelitian ini dikumpulkan melalui kuisioner daring dan wawancara. Validasi data dilaksanakan melalui triangulasi data. Hasil dari penelitian ini menunjukkan bahwa training di bagian Kantor Depan Hotel Aryaduta Bali perlu ditingkatkan pada aspek kepuasan peserta dan efektivitas evaluasi. Untuk meningkatkan aspek tersebut, evaluasi anonim disarankan untuk dilakukan sehingga masukan dari peserta training dapat menjaid lebih detail dan objektif.
\end{abstract}

Kata Kunci: Evaluasi Training, Model Kirkpatrick's, Pelatihan

\section{A. INTRODUCTION}

Aryaduta Bali Hotel is a five-star hotel in Bali. Aryaduta Bali is a family hotel, which means the target market of Aryaduta Bali is family group particularly the Australian, Asian and domestic tourists. The location of Aryaduta Bali is strategic. It is really close to beaches, business center, restaurants, cafes, clubs, pubs, and shopping malls. To increase their quality of service, Aryaduta Bali Hotel already held training program routinely from daily, monthly and annualy. Based on the interview with the front office manager, from the training held until daily operation in front office department is already well-organized and improved by time to time.There is an evaluation for the training programs hold once in a month. However, not in accordance with a trusted and great theory to help them to find the detail list of aspects to have an effective evaluation of the training programs.There are still some bad reviews from online travel agents such as Tripadvisor and booking.com regarding the service operation. For instance, bad attitude of staff and bad service that received by the guest in 2019 hotel operation. Therefore, to increase more the quality of training program in Front Office Department at Aryaduta Bali, this research study gives a deep explanation on specific important aspects based on a trusted theory in doing effective training program evaluation.

Training program is a process through which people enhance and develop their efficiency, capability and effectiveness at work by improving and updating their knowledge, understanding and skills relevant to their job satisfaction (Rehmat, et.al., 2015). The training program will get effective result if it is

* Corresponding author

Received: September 17, 2020; Revised: November 19, 2020; Accepted: December 22, 2020 
implemented and held effectively (Samanta, 2000). The statement of definition of training from the expert shows how important effective training program is to the employee and the company that will obviously bring much impacts to many aspects such as employee job satisfaction, benefits to company, employee and guest, guest satisfaction, and hotel's rating. However, to implement the effective training program may take up some cost and consistency in doing the implementation (Zahro and $\mathrm{Wu}, 2016$ ).

The newest built Aryaduta Hotel was in 2018, which is Aryaduta Bali as a five-star hotel. Aryaduta Bali was opened on March 29th, 2018. Aryaduta Hotel is one of the members in Lippo Group by Mr. Mochtar Riady. Over the years, Aryaduta Hotels have grown to become one of the Indonesia's largest hotel groups with 10 hotels in key cities in Indonesia. Aryaduta Bali Hotel is located on Kartika Plaza street, Segara, Kuta, Kabupaten Badung, Bali. Aryaduta Bali has 178 rooms with 4 classification of rooms include superior room, deluxe room, deluxe premier room, and executive room. All guest rooms in Aryaduta are non-smoking rooms.In Aryaduta Bali Hotel, there are 155 total of the staff and 19 total of the training (all departments). Specifically in front office department, there are 19 total of Front Office Team. There is an training evaluation held once a month due to improve the skills and knowledge of the staff.

The theoritical framework used as the basis for this research study is Kirkpatrick (2007) theory regarding effective training program including the requirements and the steps. The researcher decided to choose this theory because it is related to the topic of this research study which is training program evaluation. Also, this theory has been commonly used for International research studies as trustworthy and great theory for their basis of research studies rather than other theories.

According to Kirkpatrick (2007), there are ten requirements for an effective training programincluding base the programs on the needs of the participants, set learning objectives, schedule the program at the right time, hold the program at the right place with right amenities, invite the right people to attend, select effective instructors, use effective techniques and aids, accomplish the program objectives, satisfy the participants, and evaluate the program. Other than that, as stated in Kirkpatrick (2007), there are four levels in conducting evaluation of training including reaction, learning, behavior, and result. For this research, the researcher used and focused on the first level of evaluation, which is reaction evaluation. It is because the purpose of this research is to evaluate the quality of the training program. Therefore, the reaction and level of satisfaction of the participants about the training program that has been heldor implemented is needed.

Kirkpatrick's theory has been used by many researchers around the world that are related to this research study topic which is training program evaluation. First is the research done by Ikramina \& Gustomo (2014) that mostly explain about the problem and gap in training program evaluation focusing on the behavioural change in behaviour level. Second research that used the theory is done by Abdulghani (2014) that more focus on evaluating the training program through assessing participant's satisfaction, knowledge and skills gain. In addition, impact on implementing the theory due to get great quality improvement for the training program. Third is the research study done by Chang (2010) which talk more about the impacts of the training program that has been held for the company in sales department and using effective evaluation model based on Kirkpatrick (2007) due to predict the future organizational impact and make better plans and decisions.

This research is conducted based on the empirical studies above as the sample. However, this research will not be the same as those research studies.This study discussed the evaluation of training programs based on the updated Kirkpatrick's theory of four-level evaluation. This research also concerned about the reaction of participants toward the training program that has been held in Front Office Department at Aryaduta Hotel Bali by Kirkpatrick (2007) ten requirements of an effective training program theory. This model is chosen since it is commonly used in research on related area. Thus this model considered trusted. The research studies which have used this model are summarized in Table 1. 
Table 1 Summary of Training Evaluation Model Used in Research

\begin{tabular}{|c|c|c|}
\hline \multirow{2}{*}{ Author } & \multicolumn{2}{|c|}{ Training Evaluation Model } \\
\cline { 2 - 3 } & $\begin{array}{c}\text { Kirkpatrick's } \\
(\mathbf{1 9 9 8 , 2 0 0 7 )}\end{array}$ & $\begin{array}{c}\text { Holton } \\
\text { (1996) }\end{array}$ \\
\hline $\begin{array}{c}\text { Fiidzah } \\
\text { Ikramina, } \\
\text { (2014) }\end{array}$ & $\checkmark$ & \\
\hline $\begin{array}{c}\text { Abdulghani, } \\
\text { (2014) }\end{array}$ & $\checkmark$ & \\
\hline $\begin{array}{c}\text { Ya-Hui } \\
\text { Chang, } \\
\text { (2010) }\end{array}$ & $\checkmark$ & \\
\hline $\begin{array}{c}\text { Pineda, } \\
\text { (2009) }\end{array}$ & $\checkmark$ & $\checkmark$ \\
\hline $\begin{array}{c}\text { Ho et al., } \\
\text { (2016) }\end{array}$ & $\checkmark$ & \\
\hline
\end{tabular}

As stated on Hayes (2009), evaluation of competence levels should be part of every training program. Providing review of important training points are helpful when on-job training is presented.By conducting effective evaluation of training program according to the trusted and great theory, Aryaduta Bali Hotel will get much more effective evaluation on training program that will enhance the skills and knowledge of the employees more. The effective theory from expert is Kirkpatrick (2007). According to Kirkpatrick (2007), evaluation after conducting training is very important for the future of the company. Evaluation of training program has a tremendous power not only to improve the quality of the training program but also to reinforce missioncritical behaviors on the job, and to demonstrate the value of their efforts (Acquaful, Dedume, and Appiah, 2016). Therefore, from the problem appeared in Aryaduta Bali Hotel focusing on the Front Office Department, it is needed for Front Office Department at Aryaduta Bali Hotel to evaluate their training program based on the trusted theory from expert which is Kirkpatrick (2007) theory. Due to improve more and to know specifically in which parts or aspects of the training program evaluation from urgent aspects until not urgent aspects that needed to improve. It will prevent much bad guest reviews and increase guest satisfaction of Front Office Department team in service operation.

The aim of the research is to analyze the quality of the training program held in Front Office Department at Aryaduta Bali Hotel based on Kirkpatrick's theory to find out possible suggestions or recommendations as the improvements. This research is more focus on the training programs in Front Office Department at Aryaduta Bali Hotel that has been held from January until December 2019. For the result of the research, this research study is expected to give deep explanation and good input to Front Office Department at Aryaduta Bali Hotel on the evaluation of their training programs effectiveness. Through this research study, Front Office Department at Aryaduta Bali Hotel could see more, analyze and consider more regarding all the aspects of the training program evaluation according to trusted theory from expert and plan better for their future improvements.

\section{B. RESEARCH METHOD}

This research study uses mixed-method research. Therefore, the data is in qualitative and quantitative. This research uses quantitative data including doing questionnaire to all the front office staff. 
While, the qualitative data of this research is conducting interview with the front office manager dan data collected by the researcher regarding the quality of training in Front Office Department at Aryaduta Bali hotel.

In collecting data, this research uses primary and secondary data as the source of data. The primary data gathered was acquired through questionnaire, and interview regarding training program in Front Office Department at Aryaduta Bali hotel. For the secondary data was acquired from documents and file from Front Office Department of Aryaduta Bali Hotel which are total employee, range of age, and job position in 2019.

The population of this research study are all employees in Front Office Department at Aryaduta Bali Hotelwith total of 19 staff. Furthermore, data source triangulation is done to validate the data. It was done to three different sources, namely the hotel's employees especiaally in Front Office Department, the general manager, hospitality senior practitioner, researchers with interest to hospitality studies and focus group discussion held by hospitality industry expert.

\section{RESULT AND ANALYSIS}

For this research study, validity test was used to measure the questionnaire as a research instrument. This validity test was processed using Pearson product moment correlation and to calculate the data use the SPSS System. The questionnaire is stated as valid if $r$-table $<r$-count. From the results of the questionnaire obtained, the value of the $r$-table for 19 respondents with a significance level of $5 \%$ is $0,456(\mathrm{df}=\mathrm{N}-2)$. It means that the questionnaire items of this research are already valid because $\mathrm{r}$-table $<$ $r$-count.

Then, to see how reliable the questionnaire even after used repeatedly, reliability test was used to measure the questionnaire.By using SPSS, this research tested the questionnaire with Cronbach Alpha which the minimum value is 0,6. From the questionnaire result, the Cronbach Alpha value is 0.940 . Therefore, it means the questionnaire items are reliable.

The result of the questionnaire is analysed by calculating mean score. The aim of using this type of analysis for this research study is to find the mean or statistical average answer obtained from the questionnaire that has been answered by the respondents. Data source triangulation was also done to validate the data. It was done to three different sources, namely the hotel's employees especially in Front Office Department, Front Office Manager, hospitality senior practitioner, researchers with interest tohospitality studies.

This study is using 10 indicators as the benchmark of the questionnaire. Therefore, there will be 10 mean values as the result of the calculation. After calculating the mean score, then the value obtained will be categorized using the interval class formula. The aim is to modify the values in the form of numbers into words so they can be interpreted and understood easily. The data calculation as the result of the questionnaire are summarized in Table 2.

From the questionnaire that has been done online, there are 20 statements which represent the 10 indicators, that refered to Kirkpatrick's theory of training program effectiveness indicators. Then, the statements are given to the respondents to be answered by assessing the statementsfrom 1 (Strongly disagree) until 5 (Strongly agree). By using the Mean Score formula and the Interval Class, it can be seen that the two lowest scores are obtained by indicator 9 and indicator 10. It shows that the training program needs improvements more on how to satisfy the participants and how to more effectively evaluate the program. Followed by three low scores indicators include indicator 3 , indicator 5 and indicator 8 . That also means the training need to improve more in scheduling the program at the right time, inviting the right people to attend, and accomplishing the program objectives. 
Table 2 Data Calculation

\begin{tabular}{clc}
\hline No & \multicolumn{1}{c}{ Indicator } & Score \\
\hline 1 & \multirow{2}{*}{ Base the program on the needs of the participants. } & 4,47 \\
\hline 2 & Set learning objectives. & 4,44 \\
\hline 3 & Schedule the program at the right time. & 4,26 \\
\hline \multirow{2}{*}{4} & \multirow{2}{*}{ Hold the program at the right place with the right amenities. } & 4,31 \\
\hline 5 & Invite the right people to attend. & 4,23 \\
\hline 6 & Select effective instructors. & 4,39 \\
\hline 7 & Use effective techniques and aids. & 4,31 \\
\hline \multirow{2}{*}{8} & \multirow{2}{*}{ Accomplish the program objectives. } & 4,23 \\
\hline 9 & Satisfy the participants. & 4,20 \\
\hline 10 & Evaluate the program. & 4,15 \\
\hline & \multicolumn{2}{c}{ Total Mean Score } \\
\hline
\end{tabular}

The table 3 , shows that the participants did not really feel satisfy regarding the learning technique used by the trainers. Therefore, still need some changes as improvement to carry out similar training in the future. Looking from the result of interview with front office manager regarding this indicator,the information gathered shows that, the training program that has been held is already given proper materials (theory and practice) in accordance with the needs of the participants and satisfied the participants. Usually, the front office manager will directly train by giving basics of the theory or materials about their job description and job responsibility. Then, the front office manager will attach the staff to their superiors (supervisors or senior staff). Therefore, the material given can easily understand by each of the individuals.

Table 3 Score for Criteria 9

No

Indicator

Overall

\section{Satisfy the participants}

1 The learning techniques used by trainers to provide training are effective and make participants feel satisfied.

2 It is likely to carry out similar training in the future. 
The learning techniques established by the trainers did not really match participant's expectation. Therefore, the participants (the customers) may be disappointed with the program. This is where Reaction sheets are important to measure the satisfaction of the participants. When they go back to their jobs, you should be certain that they will be saying positive things about the program. Related the analysis result above, the participants agreed that there is a possibility of the similar training programs carry out in the future. Moreover, regarding the learning technique used in the process of training program. Therefore, making a plan to make improvement in that part is needed due to increase the quality of the training program. The plan that could be used as improvement to increase the quality of the training program regarding "Satisfy the Participants" indicator is list the things that the management consider needed to be in the reaction sheets. By implementing the plan and knowing the result of the reaction sheet made, the management can get the information of participant's satisfaction level measurement. Then, it will make the management be more sure on what innovation or which learning techniques are more appropriate and effective for the participants.

Table 4 Score for Criteria 10

\begin{tabular}{lll}
\hline No & Indicator & Overall \\
\hline & Evaluate the program &
\end{tabular}

Evaluate the program

1 An evaluation is carried out after implementing the training program.

2 After the training, participants are given questions or have discussions to evaluate the implementation of the training.

Based on data in Table 4, respondents agree that evaluation has been carried out after the training program and for evaluating the training they do discussion and answer questions related to the training.According to the interview result with front office manager about the "Evaluate the Program" indicator, there have always been evaluation done once in a month regarding the training program. But, there is no documentation or data regarding the evaluation such as questionnaire or staff reviews for the training program. Which means there is no secondary data to look for or consider to be more sure in making next strategy to improve the quality of training program.

Plans for evaluation should be drawn up before the program is offered. Reaction sheets should be prepared and ready to use. Decisions should be made as to whether to evaluate learning and for what programs. If a decision is made to evaluate, a pretest may be needed to administer to the participants before the program begins. Also, if managers are going to be involved, efforts should be made to contact them in advance to get them to cooperate. Related to the analysis result above, there still need some improvements to get done due to improve the quality of the training program. Moreover, in evaluation part of the training program.

The data shown in Table 5 means from the training programs held in Front Office Department at Aryaduta Bali, the time set for implementing the training program is not really effective. But, the duration for the training program is already very good. From the interview with front office manager regarding "schedule the program at the right time" indicator, the informations gathered shows that to do training 
programs, there will be planning before doing training programs. Therefore, the training programs can be well-organized and hold in the right time (not disturbing the working-hours, break-time and etc.). Usually, there will be training hold everyday. One SOP (Standard Operation Procedure) training per day. The training will hold by the front office manager or the superiors at that time. The right time to do the training program is during the morning shift have done with their break time and when the afternoon shift just arrived. The time duration to do the training programs is 30 minutes. But, there is also a training program to refresh all of the aspects in Front Office Department operation that will be hold once in a month or once in two months with $2-3$ hours time duration.

Table 5 Score for Criteria 3

\begin{tabular}{ccc}
\hline No & Indicator & Overall \\
\hline \multicolumn{2}{c}{ Schedule the program at the right time } & \\
\hline
\end{tabular}

1 The time set for implementing the training program is effective and appropriate.

The duration of the implementation of the training program has

2 been set correctly and accordingly (not too long and not too short).

If the participants are attending at a bad time as far as they are concerned, their attitude toward the entire program might be negative. Therefore, we can see from the analysis result above from the questionnaire and interview gathered. The time set for the training programs that have been held is already good since it is already touched the indicator. In addition, for the time duration of the training programs already enough. But, still need improvements moreover in setting the time for the training programs.

Table 6 Score for Criteria 5

\begin{tabular}{lll}
\hline No & Indicator & Overall \\
\hline
\end{tabular}

Invite the Right People to Attend

1 The training provided is in accordance with what is needed.

2 The training provided is in accordance with the needs to improve performance and service quality. 
To support the data in Table 6 based on the interview result with the front office manager, the information obtained from the interview is for the regular training programs that hold everyday, obviously all the employees or staff that working in that day involved in the training programs. In fact, based on direct observation, there are some specific training programs that involve the Front Office full team. If there are some of the staff that can not attend the training program that day, usually the front office manager or the superior will divide the team into two groups. Due to effectively reach all the staff in Front Office team.

The instructor must decide,"Can I mix levels of employees and have supervisors attend with higher level managers?" The answer lies in the culture of the organization and the attitudes subordinates and bosses have toward each other. In some cases, subordinates would be afraid to speak up because higher level managers are in attendance. On the other hand, some organizations have "families" of levels attending together because they work together on the job. Related to the analysis result above, the training programs have already been in accordance with what is the participant's needed and in accordance with the aim to improve performance and service quality. But, still need improvement regarding matching the expectation of the participants. Or in other words, to matched the training program with what is the participant's actually needed.

Table 7 Score for Criteria 8

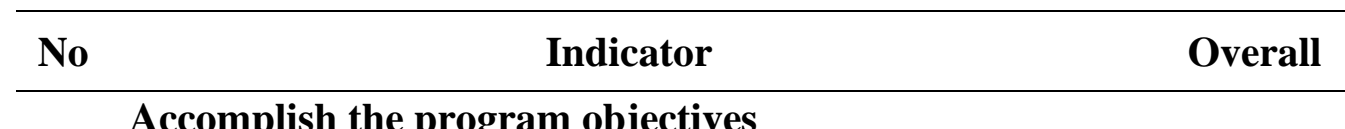

Accomplish the program objectives

1 Participants find it easier to do their work or obligations after attending a training program.

2 After conducting the training, participants can perform their obligations better.

Table 7 shows that the participants did not really find it easier to do their work after attending training programs but can do better than before attending the training programs. From the interview result with the front office manager, Based on the explanation given by the front office manager, the training programs that have been held have been accomplished the objectives. That can be seen from the result through online (travel agencies website) that Aryaduta Hotel Bali went up from rank 35 to rank 19 after intensively implementing the training program in a year. Also, from the guest reviews that show the significant increasing number of guest satisfaction because of the service given by Front Office team.

This indicator is related to second indicator which is "Set Learning Objectives" indicator. Basically, this indicator measure whether the learning objectives that have been set are reached or not. Based on the analysis result above, the training programs have been reached the objectives to perform better or increase the quality of work performance. Somehow, the participants still did not really find it easier for them to do their work after attending the training program. Therefore, an improvement focusing on that part is needed due to increase the quality of training program more.The improvement that could be done is doing reanalyze the techniques or ways to approach each of the participants. For instance, differentiate the techiques to approach each of the participants by their age. These days, the approach technique to the young-adult age from 20-30 is different with the $>30$ years old. Therefore, finding the effective approach 
technique will be the best way for the improvement of this indicator. It will also make it easier and better for the employess around 20-30 years-old to be more active to speak up during the training program. Generally, in Indonesia younger people are tend to be more silent during discussion or learning program than the older people because of the mindset where it is not really polite to speak up or talk during the discussion where older people around. Other than that, younger people in Indonesia and even in Bali are tend to be so shy to speak up if surrounded by a lot of people.

From the informations given by front office manager regarding "Base the program on the needs of the participants" indicator, the training programs held until now is already matched the needs of the participants. Since, Aryaduta Hotel management already has training manager to support and focus more on the training programs needed for the operation. Which, different with the year of 2018, where there was no training manager. Usually, the training program held in Front Office Department made by Front Office Manager itself. Then, shared to the supervisors. After the supervisors understood the materials or the topics, the supervisors can train each of the staff regarding the materials or the topics. From that way, the material of the training program can effectively reach all of the member in Front Office Department team. With that way also, the front office manager can deliver and talk about the topic personally with the supervisors or even the staff. Other than that, the supervisors can deliver and talk about the topic personally with the staff. Therefore, if the individuals have some questions to ask or even still confused at the moment related to the topic of training program, they can directly asks to the trainer personally (front office manager or/and supervisors).

From the information gathered regarding "Set learning objective" indicator, there are learning objectives that have been set in each of the training programs held. Every departments has their own learning objectives due to improve their quality of training programs including front office department. Front Office Department has been targeted to do training programs of 40-hours per year and each of the staff needed to reach every target or objectives of the training programs. For example, a training program for front desk agents about upselling. After doing the training program, each of the front desk agents will be supported and guided to achieve the objectives and targeted goal.

The information gathered from front office manager regarding "Hold the program at the right place with the right amenities" indicator,stated that the place to do the training programs in Aryaduta Hotel Bali is already have great amenities (complete equipments and supplies) to support the process of the training programs. Since, Aryaduta Hotel Bali is certified as 5-star hotel. Therefore, for the amenities also following the standard of 5-star hotel generally.

Front Office Manager of Aryaduta Bali Hotel regarding "Select effective instructors" indicator,stated that Aryaduta Bali Hotel management has a program, where they will choose two person (supervisors level) from each of the departments to be trained nicely by the training manager to train their collegues or to be a trainer. Since, the training manager in Aryaduta Hotel is a professional trainer, that really understand about the things that must be considered to be a good trainer or intructors. From the effective way to learn, appropriate communication strategy, motivate the participants, and etc.

Then, according to the explanation given by the front office manager regarding the "Use Effective Technique and Aids" indicator, there are three techniques including visual and theory, training with industry, and role play. Those three techniques have already been considered very good. Due to maintain or even improve the training program, the management could use different techniques of training in a certain range of time. Therefore, the training program could not be boring. But, could be more effective and satisfy the participants.

To summarize the explanation above, the lowest score was obtained for the criteria ofTraining Evaluation. The result could be analysed to proposed several action plans that are suggested to be done in 
order to improve the training program in Front Office Department at Aryaduta Bali Hotel. The proposed recommendations are presented in Table 9.

Table 9 Propose Recommendation

\begin{tabular}{|c|c|c|c|}
\hline No & Indicator & Improvement Needed & Remarks \\
\hline 1 & $\begin{array}{l}\text { Satisfy the } \\
\text { participants }\end{array}$ & $\begin{array}{l}\text { Create a Reaction Sheet focusing on the } \\
\text { participants satisfaction would be very } \\
\text { helpful for the management to analyse } \\
\text { more the detail parts where the } \\
\text { participants are not really satisfy in doing } \\
\text { the training program }\end{array}$ & \multirow{5}{*}{$\begin{array}{l}\text { This is urgent to be } \\
\text { conducted. It will } \\
\text { not cost much but } \\
\text { will give benefit for } \\
\text { continous } \\
\text { improvement for } \\
\text { the quality of the } \\
\text { training program }\end{array}$} \\
\hline 2 & $\begin{array}{l}\text { Evaluate the } \\
\text { program }\end{array}$ & $\begin{array}{l}\text { Using the Reaction sheets focusing on } \\
\text { overall evalution of the training programs } \\
\text { that have been held. }\end{array}$ & \\
\hline 3 & $\begin{array}{l}\text { Schedule the } \\
\text { program at the } \\
\text { right time }\end{array}$ & $\begin{array}{l}\text { Asking the participant about what time } \\
\text { that they think it would be best to do the } \\
\text { training programs and asking the superior } \\
\text { level management about the best time to } \\
\text { do the training management. }\end{array}$ & \\
\hline 4 & $\begin{array}{l}\text { Invite the right } \\
\text { people to attend }\end{array}$ & $\begin{array}{l}\text { Ensure that the participants are the people } \\
\text { whose needs are met the training program } \\
\text { content, considering the size of the group } \\
\text { due to reach all of the employees in the } \\
\text { team and considering the limitation of } \\
\text { people to attend }\end{array}$ & \\
\hline 5 & $\begin{array}{l}\text { Accomplish the } \\
\text { program } \\
\text { objectives }\end{array}$ & $\begin{array}{l}\text { Repeatedly check the participant whether } \\
\text { if they still have questions or confused on } \\
\text { how to reach the program objectives. }\end{array}$ & \\
\hline 6 & $\begin{array}{l}\text { Hold the } \\
\text { program at the } \\
\text { right place with } \\
\text { the right } \\
\text { amenities. }\end{array}$ & $\begin{array}{l}\text { Direct ask or survey to the participants } \\
\text { involved in the training program } \\
\text { regarding any needs regarding amenities } \\
\text { that they think necessary to be in the } \\
\text { training program to support the process } \\
\text { off the training programs. }\end{array}$ & \multirow{2}{*}{$\begin{array}{l}\text { This is urgent to be } \\
\text { done but will } \\
\text { affect the hotel with } \\
\text { extra cost. If } \\
\text { these action is } \\
\text { conducted, it will } \\
\text { encourage better } \\
\text { level of guest } \\
\text { satisfaction. }\end{array}$} \\
\hline 7 & $\begin{array}{l}\text { Use effective } \\
\text { techniques and } \\
\text { aids }\end{array}$ & $\begin{array}{l}\text { Making more creative learning } \\
\text { techniques and asking the participants to } \\
\text { give reviews and choose options } \\
\text { regarding the learning techniques. }\end{array}$ & \\
\hline
\end{tabular}




\section{No Indicator}

Improvement Needed

\section{Remarks}

\begin{tabular}{lll}
\hline 8 & $\begin{array}{l}\text { Select effective } \\
\text { instructors }\end{array}$ & $\begin{array}{l}\text { Inviting professional intructors from } \\
\text { outside of the hotel such as professional } \\
\text { instructors from other Aryaduta chain. } \\
\text { (e.g. Aryaduta Lippo Cikarang (Older } \\
\text { than Aryaduta Bali Hotel)) }\end{array}$ \\
\hline $9 \begin{array}{l}\text { Set learning } \\
\text { objectives }\end{array}$ & $\begin{array}{l}\text { Clearly deliever to the participants } \\
\text { regarding the objectives and consider } \\
\text { developing objectives that reflect to } \\
\text { expected behaviour change on the job }\end{array}$ \\
\hline
\end{tabular}

Ask the participants directly through survey about what knowledge and skill that they feel they need to know and do

Base the 10 program of the needs of the participants due to do their job better, ask the superiors or even the front office manager regarding the training needs for the subordinates, ask the subordinates regarding the training needs for the superiors and study the performance appraisals of the participants.
These need extra cost. But the urgency of the indicators are lesser than the previous points.

\section{CONCLUSIONS}

From the discussion of this research study regarding 10 indicators above, that shows there are two indicators with the lowest number based on the result of the mean score analysis including "Satisfy the Participants" indicator, and "Evaluate the Program" indicator. Followed by the three indicators that have low number of mean score but not the lowest including "Schedule the program at the right time" indicator, "Invite the right people to attend" indicator, and "Accomplish the program objectives" indicator. Then, for the other five indicators are already good, just need to maintain and improvements to make them better. All of the improvements needed for each of the indicators are already stated above in improvements table.

This research study has several strengths and weaknesses in many aspects. But also, challenge and opportunity faced when conducted the research. First for the strengths are this research has explained in deep about training programs that have been held in Front Office Department. Therefore, this research study is very useful to support the management to know in detail and specific regarding the quality of training programs that have been held in Front Office Department. Second, this research study provide the explanation about the effective training program implementation based on theory from experts. Therefore, the management especially that involve in conducting training program in Front Office 


\section{REFERENCES}

Acquaful, G., Dedume, V., and Appiah, S. (2016). Staff Training and Development in the Hospitality Industry, Problems, and Challenges - A Comparative Study of SSNIT and KNUST Guest Houses at Kumasi in the Ashanti Region of Ghana. International Journal of Management and Commerce Innovations, 3(2),179-195.

Abdulghani, H.M. (2014). Research Methodology Workshops Evaluation using Kirkpatrick's Model. London: Informa UK Limited Co.

Chang, Y.H.E. (2010). An Empirical Study of Kirkpatrick's Evaluation Model in the Hospitality Industry. (IU Electronic Theses and Dissertations).

Hayes, D.K. (2009). Human Resources Management in the Hospitality Industry. New Jersey: Wiley.

Kirkpatrick, D.L. (2007). Implementing the Four Levels. Berrett-Koehler Publishers. San Fransisco: Berret-Koehler Publisher, Inc.

Ikramina \& Gustomo, (2014). Analysis of Training Evaluation Process using KirkPatrick's Training Evaluation Model. Bandung: Institute of Technology Bandung

Ho, et.al. (2016) Exploration of hotel managers' training evaluation practices and perceptions utilizing Kirkpatrick's and Phillips's models. Journal of Human Resources in Hospitality \& Tourism, 15(2), 184-208, DOI: 10.1080/15332845.2016.1084861.

Rehmat, W., Aaltio, I., Agha, M. and Khan, H. (2015). Is Training Effective? Evaluating Training Effectiveness in Call Centers. Electronic Journal of Business Ethics and Organization Studies, 20(1), 4-11.

Samanta, R.K. (2000). Training Methods for Management and Development. Atlanta: MD Publication.

Ulum, Ö. (2015). Program Evaluation through Kirkpatrick's Framework. Pacific Business Review International, 8(1), $106-109$.

Zahro, S. and Wu, M. (2016). Implementing of the employees training evaluation using Kirkpatrick's model in tourism industry - A case study. International Journal of Innovation and Applied Studies, 17(3), 1042-1049. 
Analysis of Training Program in Front Office Department at Aryaduta Bali Hotel

Luh Putu Diah Ayu Savitri, I Gusti Agung Gede Witarsana, Desak Gede Chandra Widayanthi, I Wayan Restu Darmawan

Halaman ini sengaja dikosongkan

68 | Barista: Jurnal Kajian Bahasa dan Pariwisata, Volume 7 Nomor 2, 2020: 56-68 